\title{
Gender differences and new venture performance
}

\author{
Mayank Jaiswal
Rider University, Lawrenceville, Jersey, USA \\ Mayank Jaiswal
Rider University, Lawrenceville, Jersey, USA
}

\begin{abstract}
Purpose - This study compares the performance of female majority-owned new ventures (FNV) vs. male majority-owned new ventures (MNV). It analyzes the differences in levels of variables such as education, the same industry work experience of owners, and other venture level attributes between FNVs and MNVs. More importantly, this study employs decomposition techniques to determine the individual contribution from the intergender difference of each attribute on the performance of the new venture. For example, the study finds that, on average, the owners of an MNV possessed 3.4 years more of the same industry work experience than their FNV counterparts. This difference in work experience accounted for $47 \%$ of the "explained" gap [1] in Net Profits between the FNVs and MNVs.

Design/methodology/approach - This paper utilizes the Kauffman Firm Survey, a longitudinal dataset of 4,928 new ventures started in the USA in 2004. It employs Blinder-Oaxaca and Fairlie decomposition techniques in conjunction with OLS and Logit regressions. Both methods provide point estimates of contributions to the performance gap due to the heterogeneity in each attribute across the groups (FNV and MNV). This approach has a significant advantage over OLS or mediation analysis, which can only provide a directional analysis of the contributions of differences in attributes to performance.

Findings - The paper finds no performance gap between MNVs and FNVs. It further investigates whether the heterogeneous characteristics of MNVs vs FNVs are related to different effects on survival and performance. It finds that characteristics such as owners' work experience in the same industry, average hours worked by owners in the new venture, the technology level of the venture, and its incorporation status are related with a differential impact on new venture survival and performance.

Research limitations/implications - All firms in the dataset belonged to a single cohort (2004) of new ventures started in the US. Future studies are encouraged to develop a dataset from multiple geographies and founding over several years so that the results may be more generalizable.

Practical implications - The paper provides crucial practical guidance to policymakers, investors, and entrepreneurs. In general, policies that enhance the work experience of women entrepreneurs and provide access to infrastructure such as daycares, which may allow them to work more hours, would probably improve the performance of FNVs.

Originality/value - The paper furthers the literature on women entrepreneurship by analyzing point estimates of differential contribution of disparate variables to performance. From a methodological perspective, the study reconciles the results between regression and decomposition analyses.
\end{abstract}

Keywords Entrepreneurship, Gender, Owner characteristics, New venture performance

Paper type Research paper

\section{Introduction}

As of 2017, there were an estimated 11.6 million female majority-owned businesses (FNVs) in the USA. These businesses generated revenues worth $\$ 1.7$ trillion and employed close to 9 million people (American Express, 2017). FNVs account for $38 \%$ of firms in the US (US Bureau of Labor Statistics, 2015). Over a 20-year period, 1997-2017, the number of FNVs grew by $114 \%$ compared to the national average growth rate of $44 \%$ across all businesses

(C) Mayank Jaiswal. Published in New England Journal of Entrepreneurship. Published by Emerald Publishing Limited. This article is published under the Creative Commons Attribution (CC BY 4.0) license. Anyone may reproduce, distribute, translate and create derivative works of this article (for both commercial and non-commercial purposes), subject to full attribution to the original publication and authors. The full terms of this license may be seen at http://creativecommons.org/licences/by/4.0/legalcode

The author acknowledges the Ewing Marion Kauffman Foundation and the NORC Data Enclave for providing researcher support and access to the data used in this research.

Received 23 August 2019 Revised 28 January 2020 22 April 2020

Accepted 26 April 2020 
NEJE

23,1

(American Express, 2017). While these are impressive statistics, the performance of FNVs compared to MNVs (male majority-owned ventures) has been a topic of significant debate in academia. Multiple metrics of firm performance, such as closure rates, profits, and sales have been used to study the gender differences in firm performance (Bosma et al., 2004; Fairlie and Robb, 2009; Fasci and Valdez, 1998; Honig, 1998; Robb, 2002). A literature review conducted by Klapper and Parker (2010) concludes that female-owned firms underperform male-owned firms. On the other hand, a review by Jennings and Brush (2013) points to studies such as Robb and Watson (2012) and Watson (2002) that show no difference in performance between the two categories.

As a starting point, this study assesses whether a performance gap exists between FNVs and MNVs. However, a crucial contribution of this paper regarding the performance debate is a comparative analysis of FNV vs MNV attributes. The study empirically isolates the differential contribution to performance due to a difference in the level of the same attribute across FNVs and MNVs. Fischer et al. (1993) and Robb and Watson (2012) propose that MNV vs FNV owners may differ in traits, skills, and preferences, but these differences may be mutually canceling their impact on the outcomes of the ventures. Bird and Brush (2002) and James (2012) observe that relatively scant research attention has been paid to investigating such differential impacts. The current study proposes to fill this research gap.

Most past studies, with the notable exception of Fairlie and Robb (2009), assess the impact of gender on firm performance using two broad approaches. In the first approach, a gender dummy variable is incorporated in regressions (Cooper et al., 1994; Fairlie and Robb, 2009 Justo et al., 2015; Kalnins and Williams, 2014; Lawter et al., 2016; Robb and Watson, 2012; Watson, 2002) and the size and sign of the coefficient are utilized to assess the impact of gender on performance. In the second approach, analysis is conducted only on FNVs, and variables that are hypothesized to impact the performance of this subset are input in the regression models (Azam Roomi et al., 2009; Huamg et al., 2012; Lerner et al., 1997). Both the approaches mentioned above further our understanding of what drives performance in FNVs. Yet, this study argues that it is vital to proceed to the next level and understand how the FNVs and MNVs differ in levels of the same attribute and, more importantly, how these differences impact venture performance. Multiple studies have documented the difference in MNVs vs FNVs on characteristics such as work experience, education, hours worked (Dilli and Westerhuis, 2018; Fasci and Valdez, 1998; Fairlie and Robb, 2009; Watson, 2002). However, it is essential to unpack the impact these differences have on the performance of a new venture. This unbundling not only furthers our understanding of how these attributes influence performance but also is crucial for policymakers, investors, and entrepreneurs themselves. The results of this analysis could inform policymakers on whether policy support for new ventures needs to be tailored as per the gender ownership of the new venture. Similarly, investors and entrepreneurs will be better informed about potential pitfalls given the gender ownership structure of the new venture, and hence, will be better prepared to navigate the challenges.

An investigation along the lines stated above required a couple of prerequisites; first, the data had to be detailed and extensive. Second, econometric techniques had to be identified, which could parse out the individual differential contributions by each attribute. The restricted access Kauffman Firm Survey (KFS), an eight-year panel dataset of new ventures representative of the new ventures of the US economy, was used for this study. The dataset contains an abundance of variables that capture data on the entire owner team. The richness of data allowed for testing of multiple relevant hypotheses, and more precise empirical analysis as compared to say the Fairlie and Robb (2009) study (refer Note 2 for other limitations of the Fairlie and Robb, 2009 study, which have been addressed in the current study). The Fairlie (2005) and Blinder-Oaxaca (Blinder, 1973; Oaxaca, 1973) decomposition methods were utilized in conjunction with Logit and OLS models in this 
study. These methods allowed for assessing the differential impact of an attribute on performance across the two groups.

As noted earlier, this study first assesses whether there is a gap in performance, such as survival, sales, and net profits between MNVs and FNVs. As suggested in past studies (Watson and Robb and Robinson, 2012), multiple independent and control variables were included. Second, a gap analysis of the levels of the same attribute between the two groups is conducted. The attributes studied included those that are correlated with venture performance in general, for example, same industry work experience, education (Cooper et al., 1994; refer Gilbert et al., 2006 for a literature review) or support (hamper) the performance of women-owned ventures (Azam Roomi et al., 2009; Huamg et al., 2012; Lerner et al., 1997). Variables in the latter category include technology levels and the number of hours worked by owners.

This paper is organized as follows: the next section (2) provides the theoretical underpinnings of attributes to be studied and develops hypotheses; in Section 3, the data sample and the decomposition methodology are explained; Section 4 provides a discussion of the results; Section 5 explains the various robustness checks and discusses endogeneity concerns; and finally, in section 6 , a discussion of the implications of the research is furnished.

\section{Literature review and theory}

Considerable prior research has been conducted to examine gender-based firm performance gaps (Bosma et al., 2004; Fairlie and Robb, 2009; Fasci and Valdez, 1998; Honig, 1998; Loscocco et al., 1991; Robb, 2002; Rosa et al., 1996). Most studies focus on outcomes such as survival, revenues and profits; some other outcomes studied include modes of internationalization (Pergelova et al., 2018) and networking differences (Watson, 2012). There is, in this literature, a general consensus that FNVs underperform and are smaller than MNVs (Cliff, 1998; Sabarwal and Terrell, 2008). However, there are exceptions, such as Kalnins and Williams (2014), who find that in specific contexts, female-owned ventures may last longer than male-owned ventures. Robb and Watson (2012) argue that the omission of firm age, size, scale, owner risk and demographic controls may have led to the performance gap.

It is essential to understand the drivers of new venture performance to assess how differences across FNVs and MNVs in these drivers impact performance. Human capital has been identified by many studies to be correlated with new venture performance (Cassar, 2006; Unger et al., 2011). The basic premise of the human capital theory is that an increase in an individual's knowledge should lead to an increase in their cognitive ability, which, in turn, should help them to be more productive and efficient (Becker, 1964; Schultz, 1959; Mincer, 1974). Thus, individuals with higher human capital should be better able to identify and capitalize on profitable economic opportunities. Blundell et al. (1999) view human capital as acquired or innate abilities of an individual and skills acquired by an individual through formalized education or on the job training. Becker (2009) posits that human capital seems to be linked to an individual's years of schooling. Davidsson and Honig (2003) add that the practical learning obtained from on the job training and nontraditional technical training also comprise human capital. This study analyzed the direct and secondary effects of the human capital of MNVs and FNVs on the performance of new ventures.

\subsection{Gender and new venture performance}

As noted above, many large sample studies report that female-owned ventures perform worse than male-owned ventures on multiple measures of performance. See Gatewood et al. (2003) for a comprehensive review of the literature and Coleman (2002) for a discussion of differences and new venture performance 
NEJE

23,1

constraints faced by female-owned firms. Previous studies point to differences in human capital, such as education, work experience, or financial capital, as some of the many reasons for the underperformance of FNVs. Historically, women are less likely to be employed in managerial occupations and, on average, have fewer years of work experience compared to men (Boden, 1999; US Bureau of Labor, 2015). This study suggests that the lag in work experience should not only lead to lower levels of human capital but also constrain the women in attaining relevant human capital in the future. Jovanovic (1994) and Lucas (1978) both agree that managerial expertise is essential for entrepreneurial success. Furthermore, a greater proportion of women work part-time as compared to men (US Bureau of Labor Statistics, 2015), which may slow the accumulation of managerial and other human capital essential for entrepreneurship in women compared to men. On the education front, the gap in educational attainment is closing (US Bureau of Labor Statistics, 2015). However, the aversion for risk (Powell and Ansic, 1997) and the domestic duties of females may lead to even highly educated women choosing wage work over entrepreneurship as compared to men. Thus, although females may possess more educational human capital, they may not be employing it in new ventures.

Women earn lower wages compared to men (US Bureau of Labor Statistics, 2015). As noted above, they also work more commonly on a part-time basis. Both facts should lead to women accumulating lesser financial resources to start their ventures as compared to men. However, it may be the case that FNVs raise higher amounts of external capital as compared to MNVs, and are thus, able to cover the abovementioned gap in internal financing. Studies have shown that FNVs are not able to access external funding at levels similar to MNVs (Watson, 2006). Mukhtar (2002) reported that women strive to be significantly more in control of all aspects of business compared to their male counterparts. Cressy (1995) noted that loan capital is productive for growth but reduced the control of owners over their ventures and increased the influence of the banks on it. This fear of loss of control logically would dissuade female owners from seeking external capital, which would stymie the performance of their ventures.

However, some studies report that there is no gap in performance between FNVs and MNVs (Johnsen and McMahon, 2005; Robb and Watson, 2012), positing that not enough controls have been used in past large sample studies, which leads to a performance gap. Kalnins and Williams (2014) and Fischer et al. (1993) also propose that owners of FNVs and MNVs may differ in traits and skills, but the effects of these differences cancel each other out.

Therefore, following from the above discussion, this study posits that a performance gap should exist between FNVs and MNVs. Yet, at the same time, further analysis should be conducted regarding the differences in FNV and MNV attributes. The above arguments lead to the following hypothesis:

H1. FNVs will be associated with lower levels of performance compared to MNVs.

Difference in Work Experience in the Same Industry between MNV and FNV owners and its impact on New Venture Performance

Work experience in the same industry is an important form of human capital (Becker, 1964). Numerous studies have shown that human capital of the founders by virtue of the work experience in a similar industry is positively correlated with the starting and the performance of a new venture (Colombo and Grilli, 2005; Cooper et al., 1994; Dahl and Reichstein, 2007; Weidhaas, 2018; Xu, 2019). Founders who have worked in an industry in which they start a venture can leverage contacts with buyers, suppliers, and other stakeholders to operate their enterprise cost-efficiently. Past industry experience may also lead to the development of tacit knowledge, which is tough to imitate and takes time to acquire (Mahoney and Pandian, 1992) in the short term (Dierickx and Cool, 1989). Such a resource would lead to a sustainable competitive advantage for the new venture. Industry-specific knowledge may also lead to the 
development of intuition about profitable niches in the market (Brüderl et al., 1992; Gruber et al., 2013) and a better understanding of the needs of the customer (Delmar and Shane, 2006; Knight, 1921). Rasmussen et al. (2011) find that an entrepreneurial team with past industry experience can leverage that knowledge to develop a viable business opportunity. Finally, entrepreneurs rely on content that is readily available in their memory when making strategic decisions (Fern et al., 2012). Prior industry experience of the founders should increase the "bank of memory" upon which they can draw, hence reducing their perceived risk (Norton and Moore, 2006). Thus, it can be argued that the same industry work experience will impact new venture performance.

Multiple studies have reported that women may not have similar levels of work experience as men (Cooper et al., 1994; Fairlie and Robb, 2009). Individuals tend to start ventures in industries where they have experience. Thus, this study argues that this difference should also be prevalent in owners of MNVs vs FNVs. Multiple reasons can be identified for the gap such as more proportion of women than men working part-time (US Bureau of Labor Statistics, 2015), women being responsible for home duties and striving for better work-life balance (Boden, 1999; Jennings and McDougald, 2007; Kepler and Shane, 2007). Women may also interrupt their professional careers more times than men due to reasons such as maternity or taking care of the family (Anderson et al., 2012; Kaplan, 1988), which may adversely impact their level of industry experience.

The above arguments lead to the following hypothesis:

H2. (a) The owners of FNVs possess lower levels of same industry work experience compared to owners of MNVs.

(b) The difference in the same industry work experience between the owners of FNVs and MNVs will contribute to the performance gap between FNVs and MNVs.

Difference in Education levels between MNV and FNV owners and its impact on New Venture Performance.

Education is considered an essential element of human capital (Becker, 1964). Ployhart and Moliterno (2011) propose that level and area of education are important forms of human capital for the success of businesses. Formal education develops the skills and knowledge of an individual, relevant to productive activities (Robeyns, 2006). Marvel and Lumpkin (2007) argue that schooling is an investment in human capital. Van der Sluis et al. (2008) conclude in their literature review that education is correlated with higher performance of new ventures. Knowledge-based human capital provides tough to imitate or trade resources, thus increasing the sustainability of the completive advantage created by it (Barney, 2000; Teece, 1998). One of the most critical resources of a new venture is its founders, since they may bring knowledge about the service or product, which leads to sales. Founders who possess highquality educational human capital are likely to have better judgment about opportunities and will also be able to attract and recruit high-quality employees.

However, results from empirical studies are inconclusive regarding the relationship between new venture performance and education (Stuart and Abetti, 1990; Westhead and Cowling, 1995; Colombo and Grilli, 2005). Higher levels of education may divert the individual to seek wage-based employment, which is less risky and may have better benefits as compared to entrepreneurship (Van der Sluis et al., 2008). Another logic is that formal education is not directly related to venture tasks (Marvel et al., 2014). Van der Sluis et al. (2008) also note that most past studies have studied the education of individual owners and not a team of founders, which may have different dynamics. Although the results are mixed, there seems to be a general acceptance that education enhances the knowledge and skills of individuals, and hence, should improve the prospects of new ventures.

In the first 30 years of the twentieth century (1900-1930), the proportion of male to female graduates in the US was comparable. It reached a low of 2.3 to 1 in favor of men around 1947, differences and new venture performance 
NEJE

23,1

and with changing social norms and women's expectations about their careers, it began to shift in favor of women around the 1960s. By 1980, women had again achieved parity with men in college graduation rates, and by 2003 this ratio was 1-1.35 in favor of women (Goldin et al., 2006). Women are also outperforming men in educational achievement, for example, in GPAs in school from K1-12 (Digest of Education Statistics, 2007; K12 Academics, 2019). A similar pattern emerges in college achievement (Bailey and Dynarski, 2011). It can be expected that similar patterns of education should be reflected in the owners of new ventures as well.

The above arguments lead to the following hypothesis:

H3. (a) The owners of FNVs possess higher levels of education compared to owners of MNVs.

(b) The difference in education levels between the owners of FNVs and MNVs will contribute to (narrow) the performance gap between FNVs and MNVs.

Difference in Hours worked between MNV and FNV owners and its impact on New Venture Performance

Hours spent at work by owners of a new venture could help in its survival and performance. More time at work should lead to benefits such as being able to keep the "shop" open longer, extra time to network and lower costs since a hired replacement will not be required to operate the business. Erickson (2002) argued that entrepreneurial commitment is the physical, intellectual, and emotional effort that a founder invests in a venture. Loscocco and Leitch (1993) suggested that owner commitment is pivotal for new venture performance, and the number of hours often represents owner commitment worked in a business by the owner-operators. Duckworth et al. (2007) define grit as "perseverance and passion for long term goals." Passion and hard work have been emphasized as crucial for the fulfillment of long-term goals amongst high achievers (Maddi et al., 2012). Baum and Locke (2004) posit that the passion and hard work of the entrepreneur was important for venture growth. Often, passion and hard work are proxied by the number of hours an individual spends on a project or a venture. Thus, hours worked by owners in their ventures should positively impact new venture performance.

Research has highlighted the strong and complex relationship between the business and family life of the entrepreneurs. Jennings and McDougald (2007) state that women are still typecast as the primary caregivers and nurturers of the family, and therefore, there is a high probability that they will devote less time to entrepreneurship than their male counterparts. Furthermore, men are expected to work and provide income for the family (Moore and Butner, 1997; Powell and Graves, 2003). Thus, they would work more hours at the office or their ventures than women.

The above arguments lead to the following hypothesis:

H4. (a) On average, the owners of MNVs worked more hours in their ventures compared to owners of FNVs.

(b) The difference between FNVs and MNVs in terms of the number of hours worked by owners will contribute to the performance gap between FNVs and MNVs.

Difference in Legal Form of Business between MNVs and FNVs and its impact on New Venture Performance

Kalleberg and Leicht (1991) suggest that incorporation is beneficial for the survival of a venture since incorporation lends the business an institutional identity and thus affords a business, relative financial, and legal security against dissolution. Sole proprietorships, as compared to Limited Liability Companies (LLC), represent a higher risk to the personal wealth of the owners. Thus, LLC owners can take on riskier but higher expected return projects leading to higher growth rates and better performance compared to sole proprietorships (Becchetti and Trovato, 2002; Watson, 2006). I argue that even partnerships may be more desirable for new venture performance compared to sole proprietorships since partnerships 
may bring together owners who are experts in one area, such as accounts or operations. Partnerships will also bring bigger networks and more individuals to solve problems in a business. Thus, sole proprietorships should have worse performance outcomes compared to other forms of incorporation, such as partnerships or LLCs.

Robb and Watson (2012) argue that higher proportions of FNVs are unincorporated as compared to MNVs. FNVs are smaller in size compared to MNVs. Given the costs of incorporation (one time and ongoing), MNVs may have more cash cushion to incorporate, and FNVs may favour sole proprietorship. Furthermore, MNVs, on average, tend to have more owners than FNVs. Thus, I argue that a higher proportion of FNVs should be sole proprietorships (unincorporated) compared to MNVs.

The above arguments lead to the following hypothesis:

H5. (a) A higher proportion of FNVs will be organized as sole proprietorships as compared to MNVs.

(b) The difference in the proportion of sole proprietorships between MNVs and FNVs will contribute to the performance gap between MNVs and FNVs.

Difference in technology classification between MNVs and FNVs and its impact on New Venture Performance

Ventures deemed as high technology can be associated with operating in new, novel, and emerging technology areas. High technology ventures generally employ technology such that it leads to cost efficiencies or increased value creation or both. These benefits should result in a high technology firm gaining and sustaining a competitive advantage compared to other firms inside or outside the industry (Barney, 2000). For example, Uber, a ride-hailing app and high technology venture, has shaken up the taxicab industry and pinned the relatively low technology incumbent cab companies against the ropes (Cramer and Krueger, 2016).

While, as noted above, the proportion of females earning degrees is more than males, the equation is reversed in the Science, Technology, Engineering, and Mathematics fields (STEM). Women earned 20-40\% of Bachelors, Masters, and Ph.D. degrees in the STEM fields, except for Biosciences subfield in the Sciences where they received the majority of degrees (National Science Board, 2018). Education in an area that often leads to work experience in a similar field. Given the lower levels of education amongst females as compared to males in STEM, I argue that a higher proportion of MNVs would be classified as higher technology ventures compared to FNVs. Anna et al. (2000) and Loscocco et al. (1991) find that FNVs are relatively uncommon in high technology as compared to MNVs. Bruni et al. (2004) report that women usually lack the technical skills needed for the high technology sector.

The above arguments lead to the following hypothesis:

H6. (a) A higher proportion of MNVs will be categorized as high technology ventures as compared to FNVs.

(b) The difference in the proportion of high technology categorization between MNVs and FNVs will contribute to the performance gap between MNVs and FNVs.

\section{Data and methods}

\subsection{Data}

The confidential longitudinal Kauffman Firm Survey (KFS) of new ventures has been utilized for the analyses. In all, 4,928 new ventures started in 2004, were surveyed. These firms were representative of the new ventures in the US. These firms were surveyed annually in detail from 2004 to 2011, creating an eight-year panel. A total of 3,140 firms completed the survey each year until the end of the survey period or ceased to exist as independent entities

differences and new venture performance 
NEJE

23,1

(nonrespondent firms were dropped from regressions). Out of these, firms that had a majority of either female or male owners were considered, which led to 2,756 firms. Ventures with an equal number of male and female owners were discarded; there were two reasons for this. Theoretically, the dynamics for ventures with an equal number of female and male owners could be very different from FNVs or MNVs; thus, it would not be appropriate to merge them in either category. Second, from a methodological perspective, the decomposition techniques can handle only two groups at a time.

Revenue, profit, and some other data such as total size were missing for some firms in some years. The revenues and profits are leading, and hence, 2004 revenue and profit observations were not utilized. Also, firms sometimes did not report the revenue and profit for the partial year in which they exited. The 2,756 firms generated 15,013 firm-year observations for survival, 12,041 for revenues, and 11,753 for net profits analyses.

The data provide information on up to 10 owners, initially and later, 15 owners, which includes age, gender, race, ethnicity, education, and previous experience. Detailed financial information about the ventures, location, revenues, expenses, number of employees, profit/loss, and industry classification, among many other firm-level variables, are also available in the dataset.

\subsection{Methods}

Linear Probability and Pooled Logit Models for survival were used. The Pooled Logit with year dummies is similar to survival approaches such as Cox. Fairlie and Blinder-Oaxaca decomposition techniques use the Logit model with time dummies for the base regressions. Hence, Logit was employed in survival regressions. This strategy afforded a comparison of coefficients across models. Pooled OLS regressions were employed for revenues and profits. A comparison of characteristics of the MNVs and FNVs was conducted using $t$-tests of the means. Finally, Fairlie and Blinder-Oaxaca decompositions were utilized to assess the differential contribution of each characteristic to the performance of MNVs vs FNVs.

3.2.1 Blinder-Oaxaca and Fairlie decomposition. This study proposed to understand how much of the mean gap in outcomes can be explained by the variation in observable characteristics between two groups (MNVs and FNVs). Blinder (1973) and Oaxaca (1973) developed a fundamental approach to separate the total gap in the outcome variable into explained and unexplained components. Fairlie (2005) developed an extension of the BlinderOaxaca decomposition technique, so that it may be used in nonlinear models such as Probit and Logit, which are used in survival analysis.

The Blinder-Oaxaca decomposition model is based on two separate regressions for the groups. It decomposes the average difference in the outcome variable into "explained" differences, which can be attributed to group differences in observable characteristics such as work experience or education and "unexplained" differences, which are effects due to discrimination and group differences on unobservable characteristics. Using the coefficients of OLS regressions for each group separately, the difference in mean outcome can be written as (Oaxaca and Ransom, 1994):

$$
\begin{aligned}
G= & \underbrace{\left\{E\left(X_{A}\right)-E\left(X_{B}\right)\right\}^{T}\left\{W \beta_{A}+(I-W) \beta_{B}\right\}}_{\mathrm{E}} \\
& +\underbrace{\left\{(I-W)^{T} E\left(X_{A}\right)+W^{T} E\left(X_{B}\right)\right\}^{T}\left(\beta_{A}-\beta_{B}\right)}_{\mathrm{U}}
\end{aligned}
$$

Where $E\left(X_{\mathrm{L}}\right)$ represents the vector of means of observable variables for group $L$ (here A and $\mathrm{B}$ ), and $\beta_{\mathrm{L}}$ represents the vector of OLS coefficients for each group separately, $W$ is the vector of weights, and $I$ is an identity vector. $E$ is the explained gap, and $U$ the unexplained gap. 
Oaxaca and Ransom (1994) showed that W is given by the following equation when a pooled model over the two groups is used:

$$
W_{\text {est }}=\Omega=\left(X_{A}^{T} X_{A}+X_{B}^{T} X_{B}\right)^{-1} X_{A}^{T} X_{A}
$$

According to Elder et al. (2010), the total unexplained decomposition gap corresponds to the coefficient of the dummy indicator of the group in an OLS regression. Furthermore, the pooled decomposition results of the unexplained part should lie between the values of unexplained decompositions for $W=0$ or 1 (these could be used as references for upper and lower bounds).

3.2.2 Variables. 3.2.2.1 Dependent Variables. Multiple measures of performance of new ventures were used:

Survival - a venture was recorded as surviving each year it was in business as an independent entity. Survival is coded as 1 and failure as 0 .

Log Total Revenues - are the logarithm of leading total revenues of a venture. For computational purposes, $\$ 1$ was added to the raw revenue numbers and, then a log was taken.

Log Net Profits - are the logarithm of leading net profits of a venture. Net profits can be negative, positive or zero; hence, $\$ 1$ was added to the absolute value of Net Profits, and then the $\log$ was taken. If the Net Profits were negative, the above values were multiplied by -1 .

3.2.2.2 Independent Variables and Controls. Independent Variables -

Gender Dummy - is an indicator variable representing the majority of owner-operators of a venture. Ventures with a female majority of owner-operators were coded as 0 , and those with the male majority were coded as 1 .

Average Same Industry Work Experience - The average years of work experience of the owner-operator team in an industry similar to the current venture.

Education level - Proportion of owners of the active founder team with various levels of education: 1 . High school graduate or less 2 . Technical trade or vocational degree 3 . Some college, but no degree 4. Associate's degree 5. Bachelor's degree 6. Some graduate school but no degree 7. Master's degree 8. Professional School or Doctorate

Average Hours Worked by Owner/s - Number of hours worked on average by the owneroperator team in a week (in the new venture).

Sole Proprietor - is a dummy variable, coded as 1 if the venture is a sole proprietorship and 0 otherwise.

Hi, Medium and Low Technology - are indicator variables representing the technology level (type of employees, product) of a venture. The categorization was done by KFS based on SIC classification developed by the Bureau of Labor Statistics (Hadlock et al., 1991).

\subsection{Control variables}

Multiple variables were used in the regression models to control for unobserved heterogeneity. The control variables included indicators to show whether the business provided a service or a product. Fairlie and Robb (2009) showed that the industry was not correlated with performance. Hence this study incorporated service or product instead (output-based variables). Other controls included whether the venture was based out of a home/garage, used a website, and used email. The age of the venture was also implicitly controlled since all ventures in the dataset started in 2004. The size of the venture was controlled using a log of total employees, and the number of active founders was also controlled. Owner characteristics such as average age of owners, citizenship status (US citizen or not), and race were also included in regression models.

\section{Results}

Tables 1 and 2 report regressions for Survival (Linear Probability Model and Logit), Total Revenues, and Net Profits. The Gender dummy coefficient is insignificant in all four regressions. Thus, $\mathrm{H} 1$ is not supported, echoing findings similar to Robb and Watson (2012). 
NEJE

23,1

50

As discussed earlier in the paper, the average same industry work experience, sole proprietorship and average hours worked, all impact the performance of new ventures. As the technology levels of new ventures increase, so does the performance, but some relationships are directional with low statistical significance. Education effects seem to be the weakest, and this result needs to be investigated further.

Tables 3 presents the summary statistics of MNVs vs FNVs. The two categories are statistically different in average years of work experience in the same industry, and average hours worked by owners [3], proportions of sole proprietorships, and technology levels. Thus, H2a, H4a, H5a, H6a are supported. The education levels of owners of FNVs and MNVs are not different. Statistically, both groups of entrepreneurs seem to possess slightly more education than a bachelor's degree. Thus, H3a is not supported.

Tables 4 and 5 represent the decomposition analysis of survival, total revenues, and net profits. It is worth noting that, as mentioned by Elder et al. (2010), the coefficients of the Gender Dummy in the linear regressions are very close to the unexplained gap in the Oaxaca decomposition models of survival, total revenues and net profits. The point estimates of survival decompositions, Tables $1-4$, are small, this is a direct result of the total gap between MNV and FNV survival itself being small (0.0055 and 0.0049).

Average same industry work experience accounts for a significant part of the explained gap for all outcomes. It accounts for $80 \%$ of the gap in survival, $12 \%$ in revenues, and $47 \%$ in net profits. This result makes intuitive sense since male owners, on average, possess more same industry work experience, which, in turn, leads to better ability in managing and running a startup, and hence, better performance. Thus, H2b is supported. A similar

\begin{tabular}{llc}
\hline & $\begin{array}{c}\text { Model 1: LPM } \\
\text { Coef/std err }\end{array}$ & $\begin{array}{c}\text { Model 2: Logit } \\
\text { Coef/std err }\end{array}$ \\
\hline Gender dummy & $0.005(0.01)$ & $0.130(0.09)$ \\
Average work exp (same ind) & $0.001 * * *(0.00)$ & $0.019^{* * *}(0.01)$ \\
Edu., technical & $0.014(0.01)$ & $0.272(0.21)$ \\
Edu., some Clg & $0.012(0.01)$ & $0.239(0.15)$ \\
Edu., associate & $0.002(0.01)$ & $0.093(0.18)$ \\
Edu., Bachelors & $0.013(0.01)$ & $0.264(0.14)$ \\
Edu., some grad & $0.027^{*}(0.01)$ & $0.491 *(0.23)$ \\
Edu., Masters & $0.022(0.01)$ & $0.412 *(0.17)$ \\
Edu., PhDs/Prof. & $0.029^{*}(0.01)$ & $0.551 *(0.23)$ \\
Avg. age & $0.000(0.00)$ & $0.001(0.00)$ \\
Provides product & $0.004(0.01)$ & $0.106(0.09)$ \\
Provides service & $0.015(0.01)$ & $0.308^{*}(0.12)$ \\
Sole proprietor & $0.018^{* *}(0.01)$ & $0.324^{* * *}(0.09)$ \\
Avg hrs worked & $0.000^{* * *}(0.00)$ & $0.009 * * *(0.00)$ \\
Hi tech & $0.011(0.01)$ & $0.233(0.13)$ \\
Medium tech & $0.011^{*}(0.01)$ & $0.194 *(0.10)$ \\
Prop. US Cit. & $0.015(0.02)$ & $0.622^{* * *}(0.19)$ \\
Home based & $0.004(0.01)$ & $0.067(0.10)$ \\
Website & $0.016^{* *}(0.01)$ & $0.261 * *(0.09)$ \\
Email & $0.036^{* *}(0.01)$ & $0.525^{* * *}(0.13)$ \\
Tot. active Fndrs & $0.002(0.00)$ & $0.091(0.07)$ \\
Log total employees & $0.004(0.00)$ & $0.043(0.06)$ \\
Race Controls? & Yes & Yes \\
Year Dummies? & Yes & Yes \\
Number of observations & 15,013 & 15,013 \\
$R$-sq & 0.0159 & \\
Note(s): $*<<0.05 ; * * p<0.01 ; * * * p<0.001$ & & \\
& &
\end{tabular}

Table 1.

Pooled regressions for survival

Note(s): $* p<0.05 ; * * p<0.01 ; * * * p<0.00$ 


\begin{tabular}{|c|c|c|c|}
\hline & $\begin{array}{l}\text { Model 1: Log total revenues } \\
\text { Coef/std err }\end{array}$ & $\begin{array}{l}\text { Model 2: Log net profits } \\
\text { Coef/std err }\end{array}$ & $\begin{array}{l}\text { Gender } \\
\text { differences and }\end{array}$ \\
\hline Gender dummy & $0.228(0.20)$ & $0.603(0.39)$ & \\
\hline Average work exp (Same Ind) & $0.029 * * *(0.01)$ & $0.063 * * *(0.02)$ & \\
\hline Edu., technical & $-0.735(0.41)$ & $-1.677^{*}(0.70)$ & \\
\hline Edu., some $\mathrm{Clg}$ & $-0.297(0.32)$ & $-0.905(0.62)$ & \\
\hline Edu., associate & $-0.278(0.36)$ & $-1.604 *(0.73)$ & 51 \\
\hline Edu., Bachelors & $0.340(0.30)$ & $0.029(0.58)$ & \\
\hline Edu., some grad & $0.119(0.37)$ & $-1.191(0.79)$ & \\
\hline Edu., Masters & $0.259(0.34)$ & $-0.352(0.68)$ & \\
\hline Edu., PhDs/Prof. & $-0.321(0.46)$ & $0.194(0.87)$ & \\
\hline Avg. age & $-0.011(0.01)$ & $-0.059 * * * *(0.02)$ & \\
\hline Provides product & $0.422 * *(0.15)$ & $-1.457^{* * * *}(0.32)$ & \\
\hline Provides service & $0.233(0.23)$ & $1.329 * *(0.48)$ & \\
\hline Sole proprietor & $-0.895 * * *(0.19)$ & $1.136^{* *}(0.35)$ & \\
\hline Avg hrs worked & $0.038 * * *(0.00)$ & $0.031 * * *(0.01)$ & \\
\hline Hi tech & $0.575 * *(0.21)$ & $0.479(0.52)$ & \\
\hline Medium tech & $0.254(0.17)$ & $0.972 * *(0.36)$ & \\
\hline Prop. US cit. & $0.703(0.65)$ & $0.197(1.19)$ & \\
\hline Home based & $-0.879 * * *(0.19)$ & $-0.434(0.36)$ & \\
\hline Website & $0.622 * * *(0.16)$ & $-0.469(0.34)$ & \\
\hline Email & $0.587 *(0.29)$ & $-0.030(0.53)$ & \\
\hline Tot. active fndrs & $0.086(0.12)$ & $-0.043(0.23)$ & \\
\hline Log total employees & $0.833 * * * *(0.10)$ & $-0.065(0.24)$ & \\
\hline Race controls? & Yes & Yes & \\
\hline Year dummies? & Yes & Yes & \\
\hline Number of observations & 12,041 & 11,753 & \\
\hline$R$-sq & 0.2260 & 0.0533 & Pooled reoressions for \\
\hline \multicolumn{3}{|c|}{ Note(s): $* p<0.05 ; * * p<0.01 ; * * * p<0.001$} & revenues and profits \\
\hline
\end{tabular}

explanation is valid for average hours worked by the owner team, which accounts for $20 \%$ to $46 \%$ of the gap. Thus, H4b is also supported. The analyses indicate that higher technology levels of ventures lead to better survival and performance for MNVs. However, the point estimates are small, and technology explains $2 \%$ to $12 \%$ of the explained gap. Thus, although H6b is supported, its impact is relatively modest compared to work experience and hours worked.

The interpretation of the sole proprietorship results is nuanced. For survival, it accounts for $70 \%$ to $75 \%$ and net profits $55 \%$ of the explained gap. However, the sign of the point estimate indicates that if FNVs were to incorporate at similar levels as MNVs, their survival and profits would worsen. On the other hand, for the revenues ( $20 \%$ of the explained gap), it aids in accounting for the gap. A possible explanation could be that sole proprietors are more heavily invested in their ventures. Hence, they put in extra effort in them, and this leads to the ventures surviving better and earning more profits than incorporated ventures. However, incorporated ventures or partnerships may be bigger in size leading to more resources devoted to crucial activities such as sales. Yet, as discussed above, these extra revenues do not seem to imply higher profits necessarily. Thus, H5b is statistically significant but ambivalently supported.

The effect of education levels is statistically insignificant. Thus, H2b is not supported. This result should have been expected since, as per Tables $1-3$, there is no statistically significant gap in education levels of owners of FNVs vs MNVs. The results have been summarized in Table 6. 


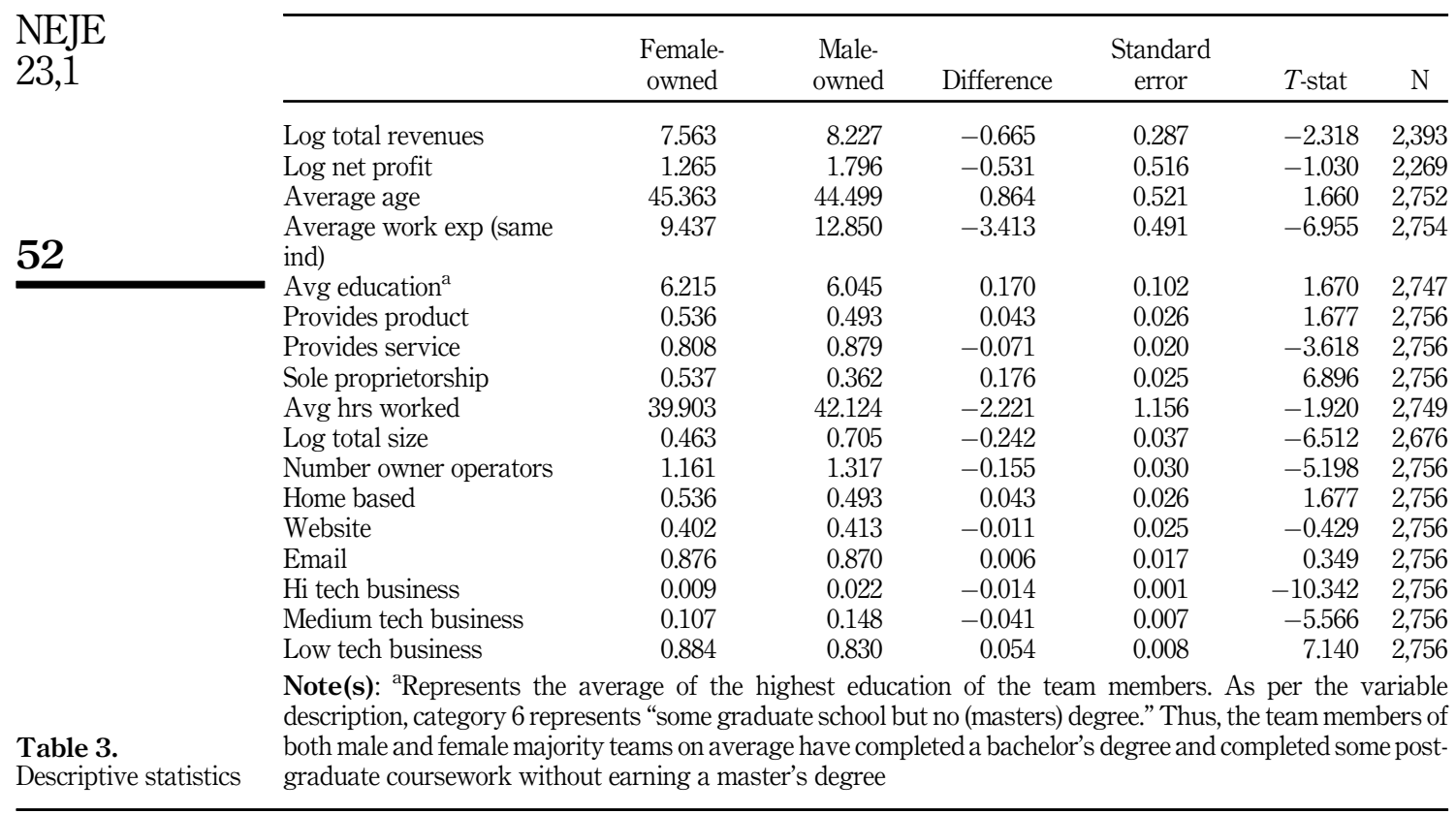

\subsection{Robustness and endogeneity}

Boundary conditions of decomposition as per Elder et al. (2010) were also tested, and it was found that the unexplained gap is between the two extremes of the male or female-only reference models [4]. The results for total revenues and net profits might be impacted by selection bias since total profits and revenues of only firms that are in business in a given year can be observed. I was unable to find instruments that are correlated with gender and uncorrelated with performance, so this remains a challenge that may be addressed in future research. It would entail collecting appropriate data so that the selection bias concern could be mitigated.

\section{Discussion and conclusion}

This study furthers our understanding of female entrepreneurship. It investigates the gap in survival and performance between FNVs and MNVs. Further, it attempts to answer the research gap in the literature about how differences in attributes between MNVs and FNVs explain the performance gap between the groups (Fischer et al., 1993; James, 2012; Robb and Watson, 2012). The study employs the KFS, an extensive and detailed dataset of new ventures, and the Blinder-Oaxaca and Fairlie decomposition techniques to parse out the differential contributions.

The analysis presented here reveals that neither performance nor survival gap exists between FNVs and MNVs. This result is similar to Robb and Watson (2012), who suggest that adequate controls lead to no performance gap between FNVs and MNVs. The view that relevant controls play an important role in empirical studies of gender is reinforced, and future research work should carefully collect and incorporate relevant controls in the analysis.

FNVs and MNVs differ in the owners' years of same industry work experience, and hours worked. They do not differ in education levels. Finally, the FNVs and MNVs have different 


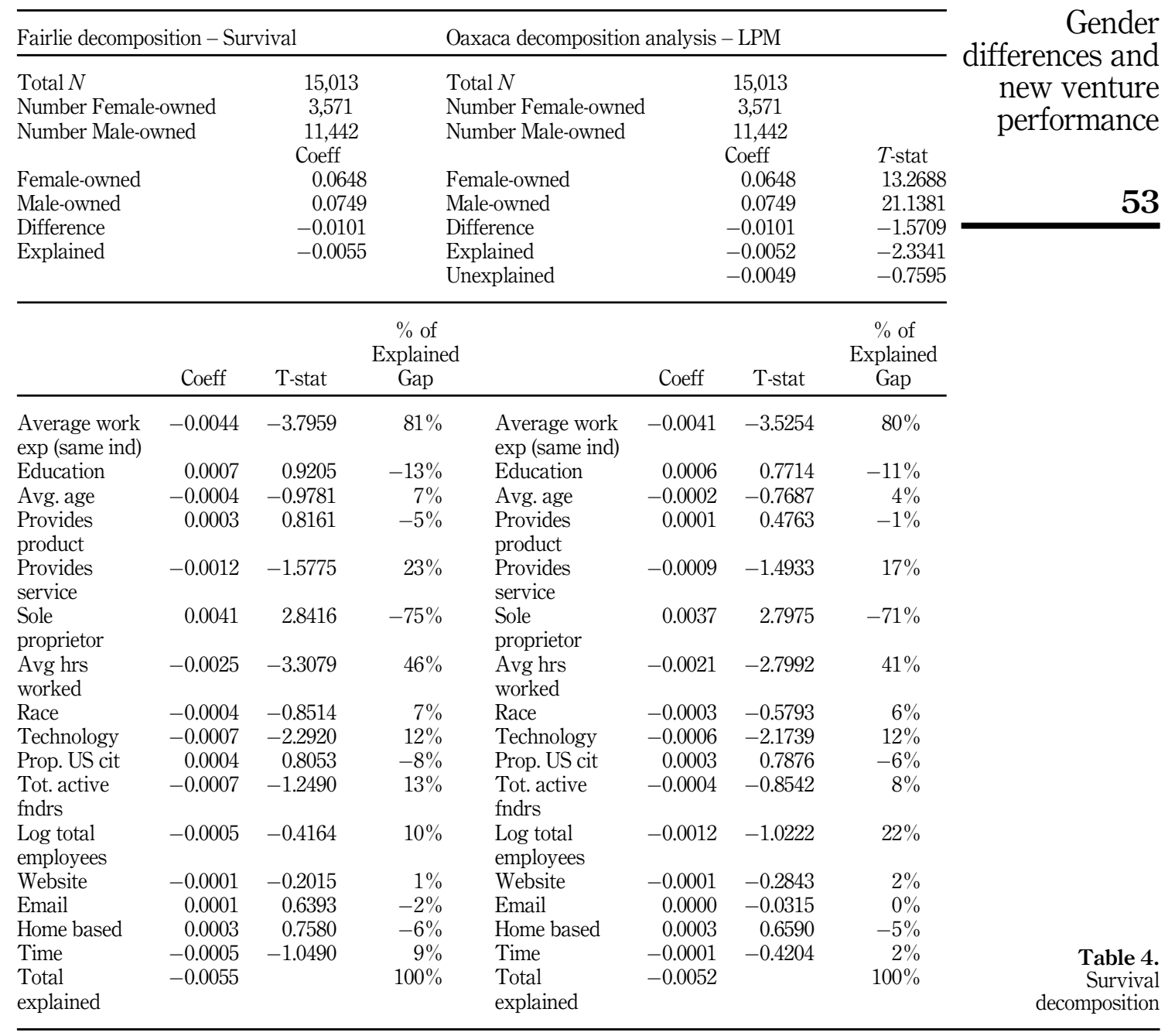

levels of sole proprietorship levels and technology categorizations of the businesses. The level of education for the owners of the two groups is similar, which is counter to the general educational trends, where females are attaining more education and achieving better scores (Bailey and Dynarski, 2011) except in STEM fields. It may be that an essential part of education attainment is its value as a signaling and screening device in the job market (Van der Sluis et al., 2008). This mechanism lets prospective employers know that an individual is qualified, thus saving the former time and effort in extensive whetting. However, in entrepreneurship, the focus is on value creation through the product or service delivered, and if an entrepreneur cannot deliver value, their business will likely fail. Hence, the owners may not have an incentive to accumulate more degrees than required to provide good value. Of course, this is a conjecture and needs to be researched further.

The average same industry work experience and average hours worked have a significant differential impact on new venture performance. First, it needs to be understood why a gap 
NEJE

23,1

Total revenues

Net profits

Total $N$

12,041

11,753

Number Female-owned

2,809

Number Male-owned

9,232

2,722

9,031

\begin{tabular}{|c|c|c|c|c|c|c|c|}
\hline 54 & \multicolumn{2}{|r|}{ Coeff } & \multicolumn{2}{|r|}{$T$-stat } & \multicolumn{2}{|c|}{ Coeff } & $T$-stat \\
\hline & $\begin{array}{l}\text { Female-owned } \\
\text { Male-owned } \\
\text { Difference } \\
\text { Explained } \\
\text { Unexplained }\end{array}$ & $\begin{array}{r}8.3082 \\
9.3984 \\
-1.0902 \\
-0.8717 \\
-0.2185\end{array}$ & \multicolumn{2}{|r|}{$\begin{array}{r}44.7269 \\
85.1416 \\
-5.0638 \\
-6.6131 \\
-1.1013\end{array}$} & \multicolumn{2}{|c|}{$\begin{array}{r}1.8899 \\
2.8912 \\
-1.0013 \\
-0.3992 \\
-0.6022\end{array}$} & $\begin{array}{r}5.7694 \\
14.6425 \\
-2.6198 \\
-2.5444 \\
-1.5832\end{array}$ \\
\hline & Total revenues - explained gap & Coeff & $T$-stat & $\%$ Explained & $\begin{array}{l}\text { Net } 1 \\
\text { Coeff }\end{array}$ & $\begin{array}{c}\text { rofits - exp } \\
T \text {-stat }\end{array}$ & $\begin{array}{l}\text { ained gap } \\
\% \text { Explained } \\
\end{array}$ \\
\hline $\begin{array}{l}\text { Table } \mathbf{5 .} \\
\text { Oaxaca decomposition } \\
\text { analysis }\end{array}$ & $\begin{array}{l}\text { Average work exp (same ind) } \\
\text { Education } \\
\text { Avg. age } \\
\text { Provides product } \\
\text { Provides service } \\
\text { Sole proprietor } \\
\text { Avg hrs worked } \\
\text { Race } \\
\text { Technology } \\
\text { Prop. US Cit } \\
\text { Tot. active fndrs } \\
\text { Log total employees } \\
\text { Website } \\
\text { Email } \\
\text { Home Based } \\
\text { Time } \\
\text { Total explained }\end{array}$ & $\begin{array}{r}-0.1037 \\
-0.0252 \\
-0.0086 \\
0.0045 \\
-0.0129 \\
-0.1783 \\
-0.1660 \\
-0.0329 \\
-0.0195 \\
0.0147 \\
-0.0140 \\
-0.2699 \\
-0.0023 \\
-0.0032 \\
-0.0526 \\
-0.0019 \\
-0.8717\end{array}$ & $\begin{array}{r}-3.1403 \\
-0.9858 \\
-0.8927 \\
0.3930 \\
-0.9668 \\
-3.9689 \\
-3.6816 \\
-0.6973 \\
-2.1236 \\
1.0243 \\
-0.8318 \\
-5.4770 \\
-0.1366 \\
-0.4233 \\
-1.9041 \\
-0.1196\end{array}$ & $\begin{array}{r}12 \% \\
3 \% \\
1 \% \\
-1 \% \\
1 \% \\
20 \% \\
19 \% \\
4 \% \\
2 \% \\
-2 \% \\
2 \% \\
31 \% \\
0 \% \\
0 \% \\
6 \% \\
0 \% \\
100 \%\end{array}$ & $\begin{array}{r}-0.1879 \\
-0.0805 \\
-0.0391 \\
-0.0143 \\
-0.0758 \\
0.2182 \\
-0.1402 \\
-0.0264 \\
-0.0492 \\
0.0047 \\
0.0030 \\
0.0199 \\
0.0001 \\
0.0003 \\
-0.0254 \\
-0.0065 \\
-0.3992\end{array}$ & $\begin{array}{r}-2.8897 \\
-1.6495 \\
-1.0982 \\
-0.3619 \\
-2.0838 \\
2.8987 \\
-2.9341 \\
-0.4308 \\
-2.2579 \\
0.1742 \\
0.0915 \\
0.2691 \\
0.0110 \\
0.0732 \\
-1.0278 \\
-0.6682\end{array}$ & $\begin{array}{r}47 \% \\
20 \% \\
10 \% \\
4 \% \\
19 \% \\
-55 \% \\
35 \% \\
7 \% \\
12 \% \\
-1 \% \\
-1 \% \\
-5 \% \\
0 \% \\
0 \% \\
6 \% \\
2 \% \\
100 \%\end{array}$ \\
\hline
\end{tabular}

\begin{tabular}{|c|c|c|c|c|c|c|}
\hline & Coeff & \multicolumn{2}{|r|}{$T$-stat } & \multicolumn{2}{|c|}{ Coeff } & $T$-stat \\
\hline Female-owned & 8.3082 & \multicolumn{2}{|r|}{44.7269} & \multicolumn{2}{|c|}{1.8899} & 5.7694 \\
\hline Male-owned & 9.3984 & \multicolumn{2}{|r|}{85.1416} & \multicolumn{2}{|c|}{2.8912} & 14.6425 \\
\hline Difference & -1.0902 & \multicolumn{2}{|r|}{-5.0638} & \multicolumn{2}{|c|}{-1.0013} & -2.6198 \\
\hline Explained & -0.8717 & \multicolumn{2}{|r|}{-6.6131} & \multicolumn{2}{|c|}{-0.3992} & -2.5444 \\
\hline Unexplained & -0.2185 & \multicolumn{2}{|r|}{-1.1013} & \multicolumn{2}{|c|}{-0.6022} & -1.5832 \\
\hline \multirow[t]{2}{*}{ Total revenues - explained gap } & & & & \multicolumn{3}{|c|}{ Net profits - explained gap } \\
\hline & Coeff & $T$-stat & $\%$ Explained & Coeff & $T$-stat & \% Explained \\
\hline Average work exp (same ind) & -0.1037 & -3.1403 & $12 \%$ & -0.1879 & -2.8897 & $47 \%$ \\
\hline Education & -0.0252 & -0.9858 & $3 \%$ & -0.0805 & -1.6495 & $20 \%$ \\
\hline Avg. age & -0.0086 & -0.8927 & $1 \%$ & -0.0391 & -1.0982 & $10 \%$ \\
\hline Provides product & 0.0045 & 0.3930 & $-1 \%$ & -0.0143 & -0.3619 & $4 \%$ \\
\hline Provides service & -0.0129 & -0.9668 & $1 \%$ & -0.0758 & -2.0838 & $19 \%$ \\
\hline Sole proprietor & -0.1783 & -3.9689 & $20 \%$ & 0.2182 & 2.8987 & $-55 \%$ \\
\hline Avg hrs worked & -0.1660 & -3.6816 & $19 \%$ & -0.1402 & -2.9341 & $35 \%$ \\
\hline Race & -0.0329 & -0.6973 & $4 \%$ & -0.0264 & -0.4308 & $7 \%$ \\
\hline Technology & -0.0195 & -2.1236 & $2 \%$ & -0.0492 & -2.2579 & $12 \%$ \\
\hline Prop. US Cit & 0.0147 & 1.0243 & $-2 \%$ & 0.0047 & 0.1742 & $-1 \%$ \\
\hline Tot. active fndrs & -0.0140 & -0.8318 & $2 \%$ & 0.0030 & 0.0915 & $-1 \%$ \\
\hline Log total employees & -0.2699 & -5.4770 & $31 \%$ & 0.0199 & 0.2691 & $-5 \%$ \\
\hline Website & -0.0023 & -0.1366 & $0 \%$ & 0.0001 & 0.0110 & $0 \%$ \\
\hline Email & -0.0032 & -0.4233 & $0 \%$ & 0.0003 & 0.0732 & $0 \%$ \\
\hline Home Based & -0.0526 & -1.9041 & $6 \%$ & -0.0254 & -1.0278 & $6 \%$ \\
\hline Time & -0.0019 & -0.1196 & $0 \%$ & -0.0065 & -0.6682 & $2 \%$ \\
\hline Total explained & -0.8717 & & $100 \%$ & -0.3992 & & $100 \%$ \\
\hline
\end{tabular}

Table 5.

Oaxaca decomposition analysis

\begin{tabular}{|c|c|c|c|}
\hline $\begin{array}{l}\text { Hypothesis } \\
\#\end{array}$ & Synopsis of hypotheses & \multicolumn{2}{|l|}{ Finding } \\
\hline $\mathrm{H} 1$ & $\begin{array}{l}\text { FNVs associated with lower performance compared to } \\
\text { MNVs }\end{array}$ & \multicolumn{2}{|c|}{ Not Supported } \\
\hline & & (a) & (b) \\
\hline $\mathrm{H} 2$ & $\begin{array}{l}\text { Average work experience in the same industry of owners of } \\
\text { MNVs vs FNVs }\end{array}$ & Supported & Supported \\
\hline H3 & Average education levels of owners of MNVs vs FNVs & $\begin{array}{l}\text { Not } \\
\text { supported }\end{array}$ & $\begin{array}{l}\text { Not } \\
\text { supported }\end{array}$ \\
\hline $\mathrm{H} 4$ & Average hours worked by owners of MNVs vs FNVs & Supported & Supported \\
\hline H5 & Legal form differences between FNVs and MNVs & Supported & Supported* \\
\hline $\mathrm{H} 6$ & Technology level differences between FNVs and MNVs & Supported & Supported \\
\hline \multicolumn{4}{|c|}{$\begin{array}{l}\text { Note(s): *Although statistically significant, the coefficient signs are ambivalent, refer Results section for } \\
\text { details }\end{array}$} \\
\hline
\end{tabular}

Table 6.

Summary of results

exists in years of work experience between the two groups. Is it an issue of mindset where women are "expected" to work less and "confirm" to the bias? In such a scenario, more focus is needed on changing the attitudes of society. On the other hand, if enough opportunities do not 
exist for women to gain work experience due to inherent biases in hiring, or women not possessing appropriate skills, the solution would be different. Similarly, women owners tend to work fewer hours, and it is crucial to research why this is the case? If it is due to expectations of performing household work, then again, attitudes in society need to be changed. However, if this is an infrastructural issue, such as the nonavailability of enough affordable daycare facilities, then the solution will be different.

The difference in technology levels does have an impact, yet the point estimates are small. It seems that starting a venture with adequate experience and putting in the hours is more important than focusing on high technology ventures for closing the performance gap between FNVs and MNVs. Regarding sole proprietorship levels, the results were mixed, while sole proprietorships are worse for survival and performance, but they are beneficial for net profits. Depending on the policy focus (revenue enhancement or profits), FNVs could be incentivized to incorporate or not.

\subsection{Limitations}

The study has certain limitations that also open avenues for future research. The ventures are all from the 2004 cohort, and from the USA, a broader data collection effort across countries and containing ventures of various cohorts may lead to wider external validity. The regressions for total revenues and net profits may suffer from survival bias since it is not possible to observe the revenues and profits of ventures that ceased to exist. Future data collection efforts should gather instrumental variables or keep in mind causal methods such as coarsened matching techniques to aid in our understanding of causality. Finally, the responses to surveys may vary depending on the gender of the person filling out the survey, but this is a limitation of the current study, and future studies could incorporate a proportional mix of men vs women respondents to address this limitation.

\subsection{Future research}

In this study, the level of education was explored. One promising avenue of research could investigate why there is no gap in education levels between owners of MNVs and FNVs. This investigation could be followed up with whether the breadth of education (for example, supply chain, finance, accounting, and human resources) has a differential impact on the performance of MNVs vs FNVs. This study focused solely on female or male majority ventures. It would be fruitful to understand the dynamics and outcomes associated with ventures, which are equally owned by males and females. Do such ventures bring out the best of both sexes or cause them to militate against each other? Are there any contexts or moderators, which increase or decrease these effects? Another potential area of research could be how gender differences interact with race, class, socioeconomic status, and other such constructs and impact new venture performance. Finally, a potential area of further research could be boundary conditions. For example, this study was based on US data. Are similar results observable in say Europe, Asia, and the Middle East?

Despite the limitations of the current study, it has far-reaching implications for researchers and policymakers. It furthers our understanding of gender-based venture performance differences and points to future fruitful avenues of research. It will also aid the policymakers, investors, and entrepreneurs in understanding the factors they need to focus on to enhance the performance of female-owned ventures.

\section{Notes}

1. The performance gap between any two groups, in this case, MNVs and FNVs, can be divided into two parts - part 1, is the difference in observed variables (such as work experience, education) of one group compared to the other. The gap in performance due to intergroup differences in such variables 
NEJE

23,1

\section{6}

is referred to as the "explained" gap. Part 2, relates to the difference in performance due to unobserved variables, which are not incorporated in the regression models, and this is termed as the "unexplained" gap. Refer Section 3.2.1 for a detailed explanation.

2. The current study provides more fine-grained data (on both dependent and independent variables), covers some more pertinent venture attributes, applies better econometric models and addresses other limitations of the Fairlie and Robb (2009) (FR) study. The FR study utilized the 1992 Characteristics of Business Owners Survey (CBO) dataset. The CBO dataset was cross-sectional (data were from 1992 except for survival measured at two points 1992 and 1996). The variables in the CBO were relatively coarse. For example, instead of a dollar amount for the profit, the survey reported profit over or under $\$ 10,000$; similarly, survival could not be tracked every year, but only once over four years plus the age of a venture could not be controlled. The FR paper does not employ the Fairlie decomposition (appropriate for nonlinear models such as Logit) for survival models. Furthermore, the FR study does not report the significance levels of the decompositions. Hence, it is challenging to understand which variables were significantly contributing to explaining the performance gap.

3. The two-tailed t-stat for the difference in average hours worked by owners of MNVs vs FNVs is -1.92 , which leads to a p-value of $5.5 \%$. Although the $p$-value is much closer to the $5 \%$ significance level, from a statistical interpretation perspective, the above result may qualify as a significance level of $10 \%$, which is still considered significant. However, it must be kept in mind that two-tailed tests are utilized under the assumption that the observed value could be either significantly below or above the hypothesized null. In this case, the difference between average hours worked by owners of MNVs vs FNVs, the null hypothesis, is that there is no difference (H0: Difference in hours worked $=0$ ). Two-tailed tests are utilized when theory is ambivalent about the direction in which the effect could be found (it could be significantly higher or significantly lower than the mean difference hypothesized in the null). However, it is well understood in the literature that on average, women do not work more hours on the job than men (refer discussion for Hypothesis 4), the question is, do they work equal or fewer hours? This argument warrants a one-tailed t-test for H4(a), and a t-stat of -1.92 for a one-tailed test is significant at the $2.75 \%$ level.

4. Results available upon request.

\section{References}

Azam Roomi, M., Harrison, P. and Beaumont-Kerridge, J. (2009), "Women-owned small and medium enterprises in England: analysis of factors influencing the growth process", Journal of Small Business and Enterprise Development, Vol. 16 No. 2, pp. 270-288.

American Express (2017), "The 2017 state of women-owned businesses report", available at: https:// about.americanexpress.com/sites/americanexpress.newshq.businesswire.com/files/doc_library/ file/2017_SWOB_Report_FINAL.pdf (accessed 14 January 2020).

Anderson, A.R., Drakopoulou Dodd, S. and Jack, S.L. (2012), "Entrepreneurship as connecting: some implications for theorising and practice", Management Decision, Vol. 50 No. 5, pp. 958-971.

Anna, A.L., Chandler, G.N., Jansen, E. and Mero, N.P. (2000), "Women business owners in traditional and non-traditional industries", Journal of Business Venturing, Vol. 15 No. 3, pp. 279-303.

Bailey, M.J. and Dynarski, S.M. (2011), Gains and Gaps: Changing Inequality in US College Entry and Completion (No. W17633), National Bureau of Economic Research, available at: https://ideas. repec.org/p/nbr/nberwo/17633.html.

Barney, J.B. (2000), "Firm resources and sustained competitive advantage", in Economics Meets Sociology in Strategic Management, Emerald Group Publishing, Bingley, pp. 203-227, available at: https://www.emerald.com/insight/content/doi/10.1016/S0742-3322(00)17018-4/full/html.

Baum, J.R. and Locke, E.A. (2004), "The relationship of entrepreneurial traits, skill, and motivation to subsequent venture growth", Journal of Applied Psychology, Vol. 89 No. 4, p. 587. 
Becchetti, L. and Trovato, G. (2002), "The determinants of growth for small and medium sized firms. The role of the availability of external finance", Small Business Economics, Vol. 19 No. 4, pp. 291-306.

Becker, G.S. (1964), Human Capital: A Theoretical and Empirical Analysis, with Special Reference to Education, Becker, London.

Gender

differences and new venture performance

Becker, G.S. (2009), Human Capital: A Theoretical and Empirical Analysis, with Special Reference to Education, University of Chicago press, Chicago, IL.

Bird, B. and Brush, C. (2002), “A gendered perspective on organizational creation”, Entrepreneurship: Theory and Practice, Vol. 26 No. 3, pp. 41-65.

Blinder, A.S. (1973), "Wage discrimination: reduced form and structural estimates”, Journal of Human Resources, pp. 436-455.

Blundell, R., Dearden, L., Meghir, C. and Sianesi, B. (1999), "Human capital investment: the returns from education and training to the individual, the firm and the economy", Fiscal Studies, Vol. 20 No. 1, pp. 1-23.

Boden, R.J. Jr (1999), "Flexible working hours, family responsibilities, and female self-employment: gender differences in self-employment selection", American Journal of Economics and Sociology, Vol. 58 No. 1, pp. 71-83.

Bosma, N., Van Praag, M., Thurik, R. and De Wit, G. (2004), "The value of human and social capital investments for the business performance of startups", Small Business Economics, Vol. 23 No. 3, pp. 227-236.

Brüderl, J., Preisendörfer, P. and Ziegler, R. (1992), "Survival chances of newly founded business organizations", American Sociological Review, pp. 227-242.

Bruni, A., Gherardi, S. and Poggio, B. (2004), "Entrepreneur-mentality, gender and the study of women entrepreneurs", Journal of Organizational Change Managemen, Vol. 17 No. 3, pp. 256-268.

Cassar, G. (2006), "Entrepreneur opportunity costs and intended venture growth", Journal of Business Venturing, Vol. 21 No. 5, pp. 610-632.

Cliff, J.E. (1998), "Does one size fit all? Exploring the relationship between attitudes towards growth, gender, and business size", Journal of Business Venturing, Vol. 13 No. 6, pp. 523-542.

Coleman, S. (2002), "Constraints faced by women small business owners: evidence from the data", Journal of Developmental Entrepreneurship, Vol. 7 No. 2, pp. 151-174.

Colombo, M.G. and Grilli, L. (2005), "Owners' human capital and the growth of new technology-based firms: a competence-based view", Research Policy, Vol. 34 No. 6, pp. 795-816.

Cooper, A.C., Gimeno-Gascon, F.J. and Woo, C.Y. (1994), "Initial human and financial capital as predictors of new venture performance", Journal of Business Venturing, Vol. 9 No. 5, pp. 371-395.

Cramer, J. and Krueger, A.B. (2016), "Disruptive change in the taxi business: the case of Uber", American Economic Review, Vol. 106 No. 5, pp. 177-82.

Cressy, R. (1995), "Business borrowing and control: a theory of entrepreneurial types", Small Business Economics, Vol. 7 No. 4, pp. 291-300.

Dahl, M.S. and Reichstein, T. (2007), "Are you experienced? Prior experience and the survival of new organizations", Industry and Innovation, Vol. 14 No. 5, pp. 497-511.

Davidsson, P. and Honig, B. (2003), "The role of social and human capital among nascent entrepreneurs", Journal of Business Venturing, Vol. 18 No. 3, pp. 301-331.

Delmar, F. and Shane, S. (2006), "Does experience matter? The effect of founding team experience on the survival and sales of newly founded ventures", Strategic Organization, Vol. 4 No. 3, pp. 215-247.

Dierickx, I. and Cool, K. (1989), "Asset stock accumulation and sustainability of competitive advantage", Management Science, Vol. 35 No. 12, pp. 1504-1511. 
NEJE 23,1

Digest of Education Statistics (2007), "K12 Academics, 2019", available at: https://nces.ed.gov/ programs/digest/d07/tables/dt07_119.asp (accessed 14 January 2020).

Dilli, S. and Westerhuis, G. (2018), "How institutions and gender differences in education shape entrepreneurial activity: a cross-national perspective", Small Business Economics, Vol. 51 No. 2, pp. 371-392.

Duckworth, A.L., Peterson, C., Matthews, M.D. and Kelly, D.R. (2007), "Grit: perseverance and passion for long-term goals", Journal of Personality and Social Psychology, Vol. 92 No. 6, p. 1087.

Elder, T.E., Goddeeris, J.H. and Haider, S.J. (2010), "Unexplained gaps and oaxaca-blinder decompositions", Labour Economics, Vol. 17 No. 1, pp. 284-290.

Erickson, Truls (2002), "Entrepreneurial capital: the emerging venture's most important asset and competitive advantage", Journal of Business Venturing, Vol. 17 No. 3, pp. 275-290.

Fairlie, R.W. (2005), "An extension of the Blinder-Oaxaca decomposition technique to logit and probit models", Journal of Economic and Social Measurement, Vol. 30 No. 4, pp. 305-316.

Fairlie, R.W. and Robb, A. (2009), "Gender differences in business performance: evidence from the Characteristics of Business Owners survey”, Small Business Economics, Vol. 33 No. 4, pp. 375-395.

Fasci, M.A. and Valdez, J. (1998), "A performance contrast of male-and female-owned small accounting practices”, Journal of Small Business Management, Vol. 36 No. 3, p. 1.

Fern, M.J., Cardinal, L.B. and O’Neill, H.M. (2012), "The genesis of strategy in new ventures: escaping the constraints of founder and team knowledge", Strategic Management Journal, Vol. 33 No. 4, pp. 427-447.

Fischer, E.M., Reuber, A.R. and Dyke, L.S. (1993), "A theoretical overview and extension of research on sex, gender, and entrepreneurship", Journal of Business Venturing, Vol. 8 No. 2, pp. 151-168.

Gatewood, E., Carter, N.M., Brush, C.G., Greene, P.G. and Hart, M.M. (2003), Women Entrepreneurs, Their Ventures, and the Venture Capital Industry: An Annotated Bibliography, Entrepreneurship and Small Business Research Institute (ESBRI), Stockholm, available at: https://www.hbs.edu/faculty/Pages/item.aspx?num=14747.

Gilbert, B.A., McDougall, P.P. and Audretsch, D.B. (2006), "New venture growth: a review and extension”, Journal of Management, Vol. 32 No. 6, pp. 926-950.

Goldin, C., Katz, L.F. and Kuziemko, I. (2006), "The homecoming of American college women: the reversal of the college gender gap”, Journal of Economic Perspectives, Vol. 20 No. 4, pp. 133-156.

Gruber, M., MacMillan, I.C. and Thompson, J.D. (2013), "Escaping the prior knowledge corridor: what shapes the number and variety of market opportunities identified before market entry of technology start-ups?”, Organization Science, Vol. 24 No. 1, pp. 280-300.

Hadlock, P., Hecker, D. and Gannon, J. (1991), "High technology employment: another view", Monthly Labor Review, Vol. 114, p. 26.

Honig, B. (1998), "What determines success? Examining the human, financial, and social capital of Jamaican microentrepreneurs”, Journal of Business Venturing, Vol. 13 No. 5, pp. 371-394.

Huamg, K.H., Mas-Tur, A. and Yu, T.H.K. (2012), "Factors affecting the success of women entrepreneurs", International Entrepreneurship and Management Journal, Vol. 8 No. 4, pp. 487-497.

James, A. (2012), “12 Conceptualizing 'woman'as an entrepreneurial advantage: a reflexive approach", Global Women's Entrepreneurship Research: Diverse Settings, Questions, and Approaches, pp. 226-241.

Jennings, J.E. and Brush, C.G. (2013), "Research on women entrepreneurs: challenges to (and from) the broader entrepreneurship literature?", The Academy of Management Annals, Vol. 7 No. 1, pp. 663-715.

Jennings, J.E. and McDougald, M.S. (2007), "Work-family interface experiences and coping strategies: implications for entrepreneurship research and practice", Academy of Management Review, Vol. 32 No. 3, pp. 747-760. 
Johnsen, G.J. and McMahon, R.G. (2005), "Owner-manager gender, financial performance and business growth amongst SMEs from Australia's business longitudinal survey”, International Small Business Journal, Vol. 23 No. 2, pp. 115-142.

Jovanovic, B. (1994), "Firm formation with heterogeneous management and labor skills", Small Business Economics, Vol. 6 No. 3, pp. 185-191.

Justo, R., DeTienne, D.R. and Sieger, P. (2015), "Failure or voluntary exit? Reassessing the female underperformance hypothesis", Journal of Business Venturing, Vol. 30 No. 6, pp. 775-792.

K12 Academics (2019), “Achievement gender gap in the United States”, available at: https://www. k12academics.com/achievement-gap-united-states/gender-gap (accessed 14 January 2020).

Kalleberg, A.L. and Leicht, K.T. (1991), "Gender and organizational performance: determinants of small business survival and success", Academy of Management Journal, Vol. 34 No. 1, pp. 136-161.

Kalnins, A. and Williams, M. (2014), "When do female-owned businesses out-survive male-owned businesses? A disaggregated approach by industry and geography", Journal of Business Venturing, Vol. 29 No. 6, pp. 822-835.

Kaplan, E. (1988), "Women entrepreneurs: constructing a framework to examine venture success and failure", In Frontiers of entrepreneurship research,(Eds) B.A. Kirchhoff, W.A. Long, W. Ed McMullan, K.H. Vesper, and W.E Wetzel, Jr (Boston, MA: Babson College, 1988), pp. 643-653.

Kepler, E. and Shane, S. (2007), “Are male and female entrepreneurs really that different?", Office of Advocacy, US Small Business Administration, No. 309, pp. 1-61, available at: http://www.pw. seipa.edu.pl/s/p/artykuly/90/909/Female\%20Entrepreneurs\%20Different \%20Shane \%202007.pdf.

Klapper, L.F. and Parker, S.C. (2010), "Gender and the business environment for new firm creation", The World Bank Research Observer, Vol. 26 No. 2, pp. 237-257.

Knight, F.H. (1921), Risk, Uncertainty and Profit, Hart, Schaffner and Marx, New York, NY.

Lawter, L., Rua, T. and Andreassi, J. (2016), "The glass cage: the gender pay gap and self-employment in the United States", New England Journal of Entrepreneurship, Vol. 19 No. 1, pp. 24-39.

Lerner, M., Brush, C. and Hisrich, R. (1997), "Israeli women entrepreneurs: an examination of factors affecting performance”, Journal of Business Venturing, Vol. 12 No. 4, pp. 315-339.

Loscocco, K.A. and Leicht, K.T. (1993), "Gender, work-family linkages, and economic success among small business owners", Journal of Marriage and the Family, Vol. 55 No. 4, pp. 875-887.

Loscocco, K.A., Robinson, J., Hall, R.H. and Allen, J.K. (1991), "Gender and small business success: an inquiry into women's relative disadvantage", Social Forces, Vol. 70 No. 1, pp. 65-85.

Lucas, Robert, E. (1978), "On the size distribution of business firms", The Bell Journal of Economics, Vol. 9 No. 2, pp. 508-523.

Maddi, S.R., Matthews, M.D., Kelly, D.R., Villarreal, B. and White, M. (2012), "The role of hardiness and grit in predicting performance and retention of USMA cadets", Military Psychology, Vol. 24 No. 1, pp. 19-28.

Mahoney, J.T. and Pandian, J.R. (1992), "The resource-based view within the conversation of strategic management", Strategic Management Journal, Vol. 13 No. 5, pp. 363-380.

Marvel, M.R. and Lumpkin, G.T. (2007), "Technology entrepreneurs' human capital and its effects on innovation radicalness", Entrepreneurship Theory and Practice, Vol. 31 No. 6, pp. 807-828.

Marvel, M.R., Davis, J.L. and Sproul, C.R. (2014), "Human capital and entrepreneurship research: a critical review and future directions", Entrepreneurship Theory and Practice, Vol. 40 No. 3, pp. 599-626.

Mincer, J. (1974). “Schooling, experience, and earnings”, Human Behavior and Social Institutions No. 2.

Mukhtar, S.M. (2002), "Differences in male and female management characteristics: a study of ownermanager businesses", Small Business Economics, Vol. 18 No. 4, pp. 289-310.

National Science Board (2018), "Chapter 2: higher education in science and engineering”, Science and Engineering Indicators, (January 2018). 
NEJE

23,1

Norton, W.I. and Moore, W.T. (2006), "The influence of entrepreneurial risk assessment on venture launch or growth decisions", Small Business Economics, Vol. 26 No. 3, pp. 215-226.

Oaxaca, R. (1973), "Male-female wage differentials in urban labor markets", International Economic Review, Vol. 14 No. 3 (October 1973), pp. 693-709.

Oaxaca, R. and Ransom, M.R. (1994), "On discrimination and the decomposition of wage differentials", Journal of Econometrics, Vol. 61 No. 1, pp. 5-21.

Pergelova, A., Angulo-Ruiz, F. and Yordanova, D.I. (2018), "Gender and international entry mode", International Small Business Journal, Vol. 36 No. 6, pp. 662-685.

Ployhart, R.E. and Moliterno, T.P. (2011), "Emergence of the human capital resource: a multilevel model", Academy of Management Review, Vol. 36 No. 1, pp. 127-150.

Powell, M. and Ansic, D. (1997), "Gender differences in risk behaviour in financial decision-making: an experimental analysis”, Journal of Economic Psychology, Vol. 18 No. 6, pp. 605-628.

Powell, G.N. and Graves, L.M. (2003), Women and Men in Management, Sage, Thousand Oaks, CA.

Rasmussen, E., Mosey, S. and Wright, M. (2011), "The evolution of entrepreneurial competencies: a longitudinal study of university spin-off venture emergence", Journal of Management Studies, Vol. 48 No. 6, pp. 1314-1345.

Robb, A. (2002), "Entrepreneurial performance by women and minorities: the case of new firms", Journal of Developmental Entrepreneurship, Vol. 7 No. 4, p. 383.

Robb, A. and Robinson, D.T. (2012), "The capital structure decisions of new firms", Review of Financial Studies, Society for Financial Studies, Vol. 27 No. 1, pp. 153-179, January.

Robb, A. and Watson, J. (2012), "Gender differences in firm performance: evidence from new ventures in the United States", Journal of Business Venturing, Vol. 27 No. 5, pp. 544-558.

Robeyns, I. (2006), "Three models of education: rights, capabilities and human capital", Theory and Research in Education, Vol. 4 No. 1, pp. 69-84.

Rosa, P., Carter, S. and Hamilton, D. (1996), "Gender as a determinant of small business performance: insights from a British study", Small Business Economics, Vol. 8 No. 6, pp. 463-478.

Sabarwal, S. and Terrell, K. (2008), Does Gender Matter for Firm Performance, Evidence from Eastern Europe and Central Asia, World Bank Policy Research Working Paper (4705), available at: https://elibrary.worldbank.org/doi/abs/10.1596/1813-9450-4705.

Schultz, T.W. (1959), "Investment in man: an economist's view”, Social Service Review, Vol. 33 No. 2, pp. 109-117.

Stuart, R.W. and Abetti, P.A. (1990), "Impact of entrepreneurial and management experience on early performance", Journal of Business Venturing, Vol. 5 No. 3, pp. 151-162.

Teece, D.J. (1998), "Capturing value from knowledge assets: the new economy, markets for know-how, and intangible assets", California Management Review, Vol. 40 No. 3, pp. 55-79.

Unger, J.M., Rauch, A., Frese, M. and Rosenbusch, N. (2011), "Human capital and entrepreneurial success: a meta-analytical review", Journal of Business Venturing, Vol. 26 No. 3, pp. 341-358.

US Bureau of Labor Statistics (2015), "Women in the labor force: a databook", available at: https:// www.bls.gov/opub/reports/womens-databook/archive/women-in-the-labor-force-a-databook2015.pdf (accessed 14 January 2020).

Van der Sluis, J., Van Praag, M. and Vijverberg, W. (2008), "Education and entrepreneurship selection and performance: a review of the empirical literature", Journal of Economic Surveys, Vol.22 No. 5, pp.795-841.

Watson, J. (2002), "Comparing the performance of male-and female-controlled businesses: relating outputs to inputs", Entrepreneurship: Theory and Practice, Vol. 26 No. 3, pp. 91-100.

Watson, J. (2006), "External funding and firm growth: comparing female-and male-controlled SMEs", Venture Capital, Vol. 8 No. 1, pp. 33-49.

Watson, J. (2012), "Networking: gender differences and the association with firm performance", International Small Business Journal, Vol. 30 No. 5, pp. 536-558. 
Weidhaas, A.D. (2018), "Female business owners hiding in plain sight", International Journal of Gender and Entrepreneurship, Vol. 10 No. 1, pp. 2-18.

Westhead, P. and Cowling, M. (1995), "Employment change in independent owner-managed hightechnology firms in Great Britain", Small Business Economics, Vol. 7 No. 2, pp. 111-140.

$\mathrm{Xu}$, Y. (2019), "The moderating effect of founding assets on the founders' human capital", New England Journal of Entrepreneurship, Vol. 22 No. 2, pp. 126-142.

\section{About the author}

Mayank Jaiswal is Assistant Professor in the College of Business Administration, Rider University. He received his Ph.D. in Strategic Management (with emphasis in Entrepreneurship) from the Georgia Institute of Technology. His professional experience includes working in the energy, agri business and social VC space. Mayank Jaiswal can be contacted at: mjaiswal@rider.edu

For instructions on how to order reprints of this article, please visit our website: 